\title{
Pensonomonoor
}

2016, vol. 75, 55-65

http://dx.doi.org/10.12657/denbio.075.006

\author{
Michal Rybniček, Petr Čermák, Ondřej Prokop, Tomáš Žid, \\ Miroslav Trnka, Tomáš Kolár̆
}

\section{Oak (Quercus spp.) response to climate differs more among sites than among species in central Czech Republic}

Received: 14 April 2015; Accepted: 7 October 2015

\begin{abstract}
Climatic parameters are the main environmental factors affecting tree growth. The main aim of the presented study was to determine whether different oak species growing under contrasting environmental conditions show different sensitivity to climatic parameters. Four oak stands with Quercus robur, Quercus petraea, Quercus polycarpa and Quercus dalechampii growing in the same area were evaluated. Standard dendrochronological methods were used for sample preparation, ring width measurements, cross-dating, chronology development, and the assessment of growth-climate response patterns. Although the species grew under different environmental conditions, their local tree-ring chronologies are highly correlated. The radial growth responses to climatic parameters differ slightly, but the response depends more on local site conditions than on the oak species. At the same time, the strongest correlations between radial growth and climatic parameters were identical among species and sites. The amount of water available in the soil was the main climate-dependent factor limiting radial growth. Approximately since the 1990s, the distribution of rainfalls within the growing season has changed at the expense of spring precipitation. The significance of relative soil moisture content during spring for oak growth increased and the significance of summer values decreased.
\end{abstract}

Keywords: Central Europe, oak, precipitation, temperature, tree rings

Addresses: M. Rybníček, T. Koláŕ, Department of Wood Science, Faculty of Forestry and Wood Technology, Mendel University in Brno, Zemědělská 3, 61300 Brno, Czech Republic; Global Change Research Institute, the Czech Academy of Science, Bělidla 986/4a, 60300 Brno, Czech Republic, e-mail: michalryb@post.cz

P. Čermák, Department of Forest Protection and Wildlife Management, Faculty of Forestry and Wood Technology, Mendel University in Brno, Zemědělská 3, 61300 Brno, Czech Republic

O. Prokop, Department of Wood Science, Faculty of Forestry and Wood Technology, Mendel University in Brno, Zemědělská 3, 61300 Brno, Czech Republic

T. Žid, Department of Forest Protection and Wildlife Management, Faculty of Forestry and Wood Technology, Mendel University in Brno, Zemědělská 3, 61300 Brno, Czech Republic M. Trnka, Department of Agrosystems and Bioclimatology, Faculty of Agronomy, Mendel University in Brno, Zemědělská 1, 61300 Brno, Czech Republic and Global Change Research Institute, the Czech Academy of Science, Bělidla 986/4a, 60300 Brno, Czech Republic 


\section{Introduction}

Deciduous oaks (Quercus spp.) are among the most important tree species for forestry in Central Europe. Oaks grow at low altitudes, which are increasingly vulnerable to drought given the regional topographic patterns and climatic predictions (e.g. Trnka et al., 2009a,b). Climatic changes observed in the last twenty years (Parry, 2000; Tolasz, 2007) as well as those predicted for the future include an increase in the frequency of "very wet days" followed by short or long dry periods. These changes in the dynamics of precipitation would be reflected in changes of available soil moisture (Trnka et al., 2009a; Trnka et al., 2014) and in the radial growth of trees (Rybníček et al., 2010a, 2012a,b). Studies dealing with climate characteristics in the Czech Republic and their impact on plants (e.g. Brázdil et al., 2009; Hlavinka et al., 2009; Možný et al., 2009) showed that there is no detectable reduction of spring precipitation after 1990, but that higher global radiation, temperature and water vapour pressure deficit increased evapotranspiration rates. This together with an earlier start of the growing season (e.g. Bauer et al., 2010; Olesen et al., 2012) essentially leads to a faster depletion of soil moisture reserves (e.g. Trnka et al., 2014). Spring and summer dry spells then potentially limit plant growth as shown on the example of field crops and grasslands (e.g. Hlavinka et al., 2009; Trnka et al., 2012). Drought increases the sensitivity to some biotic diseases and insect pest attacks and, as a consequence, it can lead to an increased risk of tree disease and mortality (e.g. Thomas et al., 2002; Allen et al., 2010, Kolář et al., 2013).

The existence of different climatic responses of the deciduous oak species growing in contrasting sites in the Czech Republic may be of key importance to assess future tree vitality and further development of diseases. Dendrochronological comparisons of oaks published so far have been based on a comparison of several oak species over large areas in Central Europe (e.g. Cedro, 2007; Friedrichs et al., 2009; Čufar et al., 2014; Ważny et al., 2014). Case studies in specific small areas have seldom been performed (e.g. Sanders et al., 2014), and never in the Czech Republic.

The main questions are: i) Do local tree-ring chronologies of different oak species differ? ii) What are the main climatic parameters affecting radial growth? iii) How does growth response to climatic factors differ in different oak species under comparable climatic conditions? iv) Have climatic parameters changed in the past decades? v) Have changes in the climate already affected the response?

\section{Materials and methods}

This research was conducted in four selected forest sites with a predominance of Quercus spp. in the protected landscape area Český kras, Czech Republic (Fig. 1) in 2012. The maximum distance between sites was less than $10 \mathrm{~km}$. All trees within the sites were located at altitudes from 305 to $350 \mathrm{~m}$ a.s.l. in the beech-oak forest vegetation zone, with an average annual precipitation of $543 \mathrm{~mm}$. The average annual temperature during the 1961-2011 monitoring period was $8.9^{\circ} \mathrm{C}$.

The four sites are a stand with Quercus robur on enriched-colluvial soil, a Quercus petraea stand on nutrient-rich soil on limestone, a stand with $Q$. polycar$p a$ and $Q$. dalechampii and their hybrids on dry and shallow soil, and a stand with Quercus petraea on normal mesotrophic soil (Tab. 1). Some studies consider these oaks as hybrids, but several authors have described both as separate species (Matyas, 1971; Požgaj \& Horváthová, 1986; Dostál, 1989; Koblížek, 1990; Jovanovič, 2000; Magic, 2006). The Q. polycarpa and $Q$. dalechampii were identified in this area (Šíma, 2007).

Twenty dominant and codominant trees were randomly selected within each site. All samples were extracted using a Pressler borer at breast height. Because the between-tree variability within a site is much higher than the within-tree variability around the stem (Bošela et al., 2014), one core per tree was extracted. Likewise Fritts (1976) suggested that for climate studies, one core per tree is sufficient if more than 14 trees are sampled. The samples were measured using the VIAS TimeTable measuring system, and the measurement and synchronization of treering sequences were carried out using PAST4 (CSCIEM). The tree-ring widths were measured with 0.01 $\mathrm{mm}$ accuracy. After measuring tree-ring widths, indi-

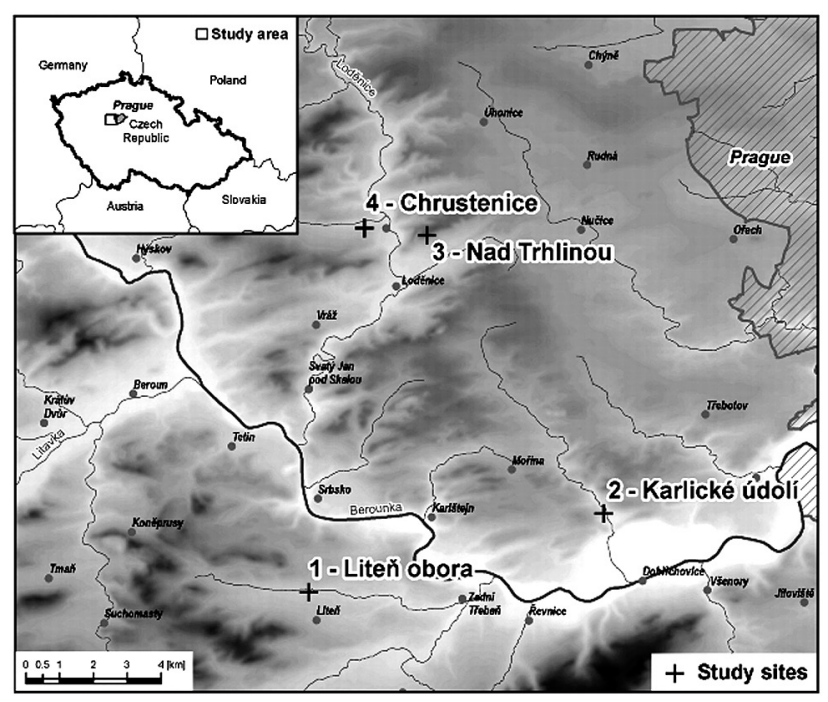

Fig. 1. Location of the study area and the sites 
Table 1. A detailed overview of the study sites. Edaphic category and Forest site complex are Czech ecosystem classification categories (Typological System of Forest Management Planning Institute) based on Viewegh et al. (2003)

\begin{tabular}{|c|c|c|c|c|c|c|c|c|c|c|}
\hline \multirow{2}{*}{ Site } & \multirow{2}{*}{ Location } & \multirow{2}{*}{$\begin{array}{c}\text { Position } \\
\begin{array}{c}\text { Lat-Long (deg., } \\
\text { min., sec.) }\end{array}\end{array}$} & \multirow{2}{*}{$\begin{array}{l}\text { Altitude } \\
(\mathrm{m} \\
\text { a.s.1. })\end{array}$} & \multicolumn{2}{|c|}{$\begin{array}{c}\text { Slope } \\
\text { gradient }\end{array}$} & \multirow{2}{*}{$\begin{array}{l}\text { Slope } \\
\text { orienta- } \\
\text { tion }\end{array}$} & \multirow{2}{*}{$\begin{array}{l}\text { Edaphic } \\
\text { category }\end{array}$} & \multirow{2}{*}{$\begin{array}{l}\text { Prevailing } \\
\text { soil types }\end{array}$} & \multirow{2}{*}{$\begin{array}{l}\text { Forest site } \\
\text { complex }\end{array}$} & \multirow{2}{*}{ Quercus species } \\
\hline & & & & $\begin{array}{l}\text { De- } \\
\text { gree }\end{array}$ & $\%$ & & & & & \\
\hline 1 & Liteň obora & $\begin{array}{l}\text { N } 495440.519 \\
\text { E } 140816.511\end{array}$ & 310 & 7 & 11 & SE & deluvia & $\begin{array}{l}\text { eutrophic } \\
\text { cambisol }\end{array}$ & $\begin{array}{l}\text { Fageto-Querce- } \\
\text { tum acerosum } \\
\text { deluvium }\end{array}$ & Quercus robur \\
\hline 2 & $\begin{array}{l}\text { Karlické } \\
\text { údoli }\end{array}$ & $\begin{array}{l}\text { N } 495646.573 \\
\text { E } 141452.067\end{array}$ & 305 & 12 & 21 & $\mathrm{NE}$ & calcaria & $\begin{array}{l}\text { calcaric } \\
\text { cambisol }\end{array}$ & $\begin{array}{c}\text { Fageto-Quercetum } \\
\text { calcarium }\end{array}$ & Quercus petraea \\
\hline 3 & $\begin{array}{l}\text { Nad } \\
\text { Trhlinou }\end{array}$ & $\begin{array}{l}\text { N } 500023.431 \\
\text { E } 141000.308\end{array}$ & 350 & 21 & 36 & SE & $\begin{array}{l}\text { subxero- } \\
\text { thermica }\end{array}$ & $\begin{array}{l}\text { cambic } \\
\text { ranker }\end{array}$ & $\begin{array}{l}\text { Fageto-Quercetum } \\
\text { subxerothermicum }\end{array}$ & $\begin{array}{c}\text { Quercus polycarpa } \\
\text { Quercus dale- } \\
\text { champii }\end{array}$ \\
\hline 4 & $\begin{array}{l}\text { Chrusten- } \\
\text { ice }\end{array}$ & $\begin{array}{l}\text { N } 500022.944 \\
\text { E } 140804.968\end{array}$ & 320 & 7 & 11 & $\mathrm{~N}$ & $\begin{array}{l}\text { eutroph- } \\
\text { ica }\end{array}$ & $\begin{array}{l}\text { mes- } \\
\text { otrophic } \\
\text { cambisol }\end{array}$ & $\begin{array}{c}\text { Fageto-Quercetum } \\
\text { eutrophicum }\end{array}$ & Quercus petraea \\
\hline
\end{tabular}

vidual tree-ring series were cross-dated. The tree-ring series which correlated significantly with each other at the $\mathrm{p}=0.01$ confidence limit was used to create an average tree-ring series. The degree of similarity between the tree-ring series and chronologies was assessed using the T-test according to Baillie \& Pilcher (1973) and T-test according to Hollstein (1980), the coefficient of agreement (Gleichläufigkeit; Eckstein \& Bauch, 1969), and a visual comparison of tree-ring series, which is crucial for the final dating (Rybníček et al., 2010b).

The tree-age-related growth trends and the autocorrelation structures were removed by using the ARSTAN application (Grissino-Mayer et al., 1992) using a single detrending method (Holmes et al., 1986). The site residual index of the tree-ring chronologies were then used to calculate the climate-growth relationship. The negative exponential function or a linear regression (Fritts et al., 1969), which best resemble the growth trends (Fig. 2), was used. Indices were calculated as a ratio between the measured tree-ring widths and their corresponding values fitted by the function. Site chronologies for each stand were calculated using a biweight robust mean. Expressed Population Signal (EPS; Wigley et al., 1984) for the period 1916-2011, when all chronologies have a minimum replication of 10 series, inter-series correlation (Rbar) and Signal-to-noise ratio (SNR; Fritts \& Swetnam, 1989) were calculated to assess the quality of each chronology (Tab. 2).

Climatic data needed for calculations for each site were derived from the $500 \mathrm{~m}$ resolution gridded daily dataset created by applying locally weighted regression and accounting for the effect of altitude. The original station based measurements used for interpolation were subjected to quality control and homogenization using ProClimDB (Štěpánek, 2007). The grided dataset covers the whole Czech Republic and is based 268 meteorological (providing fully range of weather parameters) and 787 precipitation

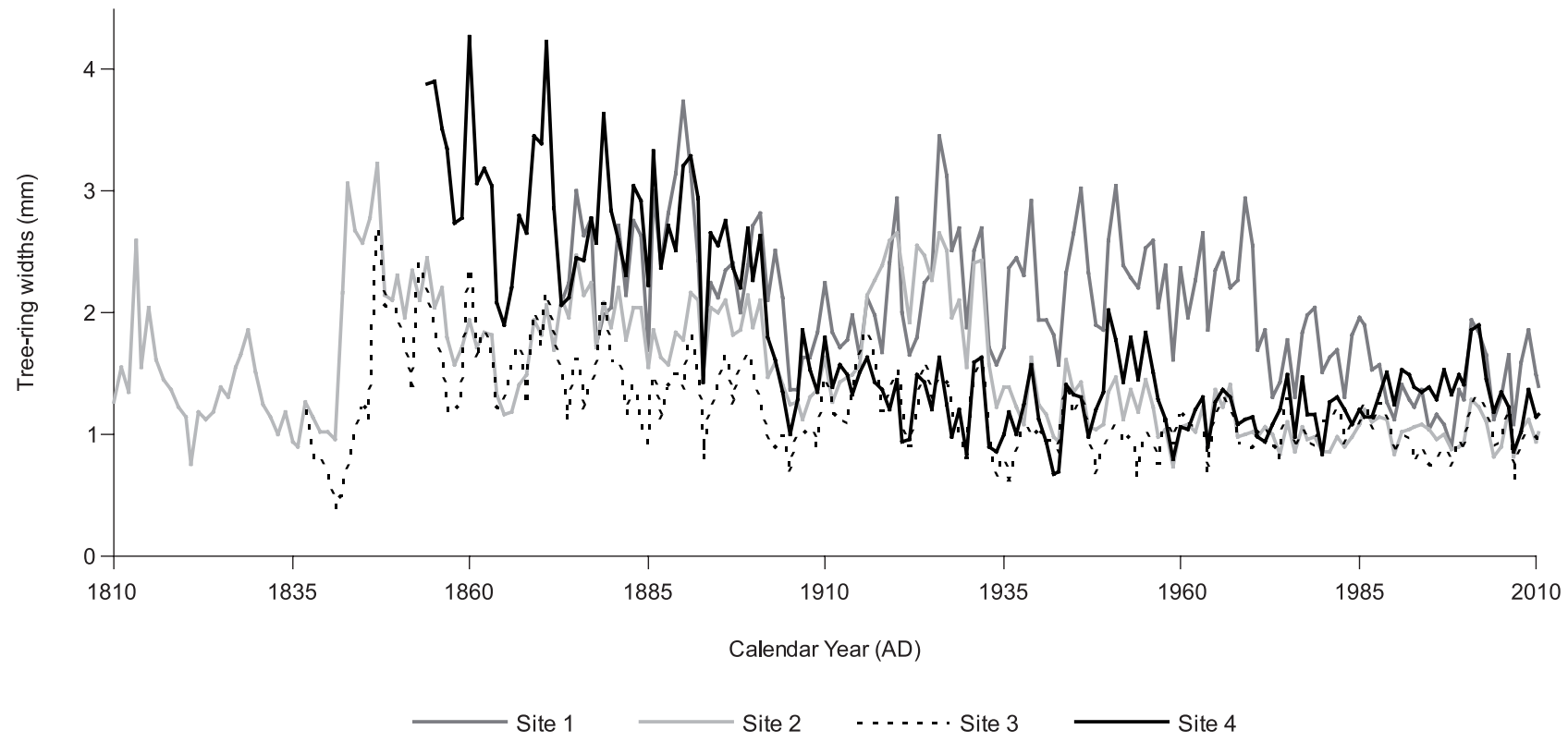

Fig. 2. Growth trends of the tree-ring width chronologies 
Table 2. Statistical characteristics of the site chronologies (TRW - tree-ring width chronology, TRWi - tree-ring width index chronology, MSL - mean segment length, AGR - average growth rate ( $\mathrm{mm})$, SD - standard deviation, Rbar - mean inter-series correlation, EPS - Expressed Population Signal (for the period 1916-2011), AC1 - first autocorrelation, SNR - Signal-to-noise ratio)

\begin{tabular}{|c|c|c|c|c|c|c|c|c|c|c|}
\hline & \multicolumn{6}{|c|}{ TRW } & \multirow{2}{*}{$\begin{array}{l}\text { TRWi } \\
\text { SNR }\end{array}$} & \multicolumn{3}{|c|}{ Site chronology } \\
\hline & MSL & AGR & SD & Rbar & EPS & AC1 & & Start & End & Length \\
\hline Site 1 & 117 & 2.01 & 0.81 & 0.64 & 0.92 & 0.65 & 9.74 & 1854 & 2011 & 158 \\
\hline Site 2 & 156 & 1.51 & 0.75 & 0.53 & 0.89 & 0.77 & 15.88 & 1807 & 2011 & 205 \\
\hline Site 3 & 156 & 1.18 & 0.52 & 0.69 & 0.93 & 0.62 & 10.93 & 1837 & 2011 & 175 \\
\hline Site 4 & 140 & 1.64 & 1.00 & 0.62 & 0.88 & 0.74 & 6.47 & 1851 & 2011 & 161 \\
\hline
\end{tabular}

stations proving daily precipitation data only. Using AgriClim (Trnka et al., 2011) and SoilClim (Hlavinka et al., 2011) software packages, daily RSMC values in $0-1.3 \mathrm{~m}$ below soil surface were calculated. The RSMC is estimated in a daily time step accounting not only for the balance between evapotranspiration, precipitation and antecedent soil moisture but also on the snow presence/absence, aspect and slope of the site, critical soil water holding properties, as well as phenological stage of the canopy. The routine is based on the Allen et al. (1998) approach and has been described in more detailed by Hlavinka et al. (2011) and Trnka et al. (2015).

DendroClim2002 was used to calculate correlation coefficients between the site residual oak chronologies and climatic drivers (i.e. temperature, precipitation, global radiation and RSMC - relative soil moisture content) in the period 1961-2011 (Biondi \& Waikul, 2004). The correlation coefficients were calculated for a seasonal window from April of the previous year until September of the year of tree-ring formation (referred to as "the current year"), i.e., for a period of 18 months. This interval has the highest influence on the radial increment of oak in Central Europe (Horáček et al., 2003; Gričar, 2010). The correlations of the current year were also calculated from March to May (when earlywood is assumed to be formed) and from June to August (typical summer months); additionally, correlations were analyzed from July to September of the previous year (thought to be a period of energy reserve formation for the next season).

\section{Results}

Site chronologies were created from twenty trees at each site. The lowest mean segment length (117) corresponds to the highest value of the average growth rate $(2.01 \mathrm{~mm})$ at site 1 . An opposite dependence can be observed at the most extreme site 3 , where narrow tree-ring widths were expected. The inter-series correlation (Rbar), Signal-to-noise ratio (SNR) and the Expressed Population Signal (EPS) reveal the signal strength (Tab. 2). The mean EPS for the well replicated period ( $>10$ series) reliably ex- ceeds the threshold of 0.85 (Wigley et al., 1984) at all sites. The values of the signal-to-noise ratio reach above 6 and are comparable with those achieved in other dendroclimatological analyses of oak, e.g. Rozas (2005).

High similarity between site TRW chronologies was found. When the tree-ring series overlap by at least one hundred and twenty years, the critical value of Student's t-distribution with $\mathrm{p}=0.001$ level of significance is 3.373 (Šmelko \& Wolf, 1977). The values of our t-tests markedly exceed the threshold which shows a high reliability of the synchronization. The correctness of the synchronization is also proved by the agreement of the average tree-ring series in most of the extreme values (Fig. 3). Strongly reduced increments common for all sites were observed in e.g. 1964, 1976, 2004, 2007 (Fig. 3).

Statistically significant correlations of the treering width with average temperatures in summer (July-September) of the previous year are negative at all sites; the highest significance has been found at site 3. Negative correlations prevail for the current year. They are always significant for one or two sites (Fig. 4).

The statistically significant tree-ring width correlations with monthly precipitation sums are only positive, with the unique exception of April of the previous year at site 2 . The highest correlations at all sites have been found for October of the previous year. The prevailing significant correlations for the current year are those with spring precipitation, with the exception of site 4 , the most significant being the correlations for sites 2 and 3.

Monthly RSMC shows the most significant effect on tree growth. The highest correlations have been found for site 3, from previous August to September of the current year. The period from previous November to August of the current year plays the key role at the other three sites with a predominant effect of March, April, and May.

The negative influence of the global radiation on tree-ring width prevails at all sites during the entire period analysed. The importance of spring months of the current year (mainly March and April) is common for all sites. Significant correlations with previous summer and autumn months were proved only 


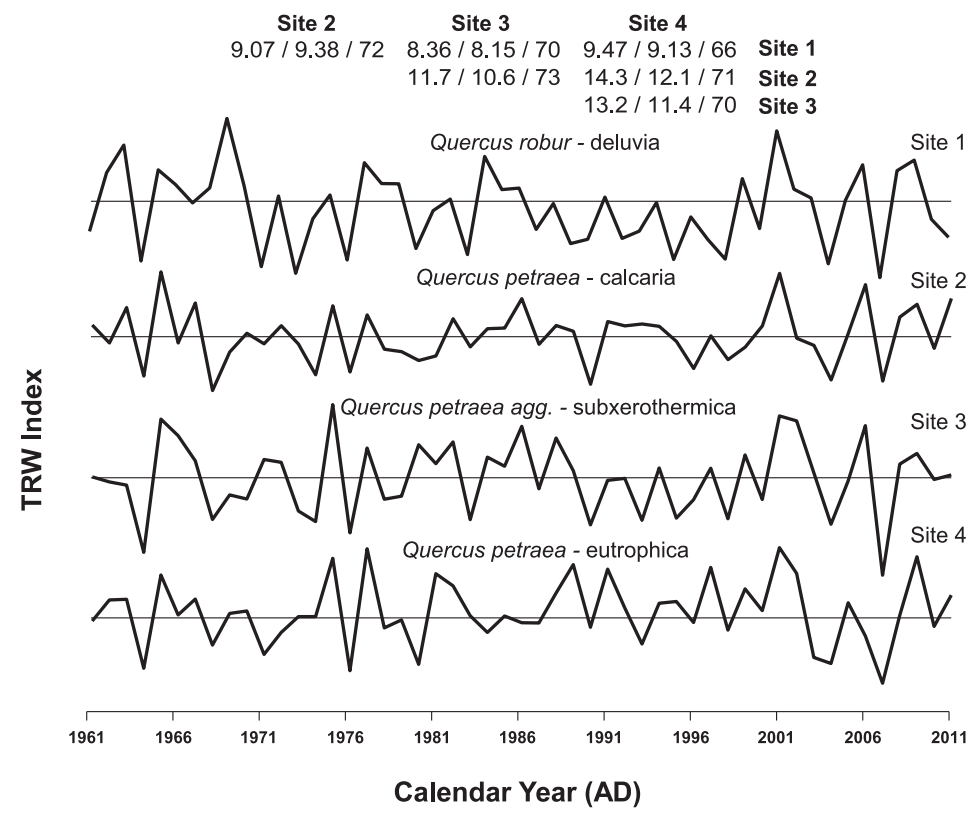

Fig. 3. Synchronization of site TRW chronologies (T-test according to Baillie \& Pilcher / T-test according to Hollstein / synchronization of tree-ring series in \% (Gleichläufigkeit))
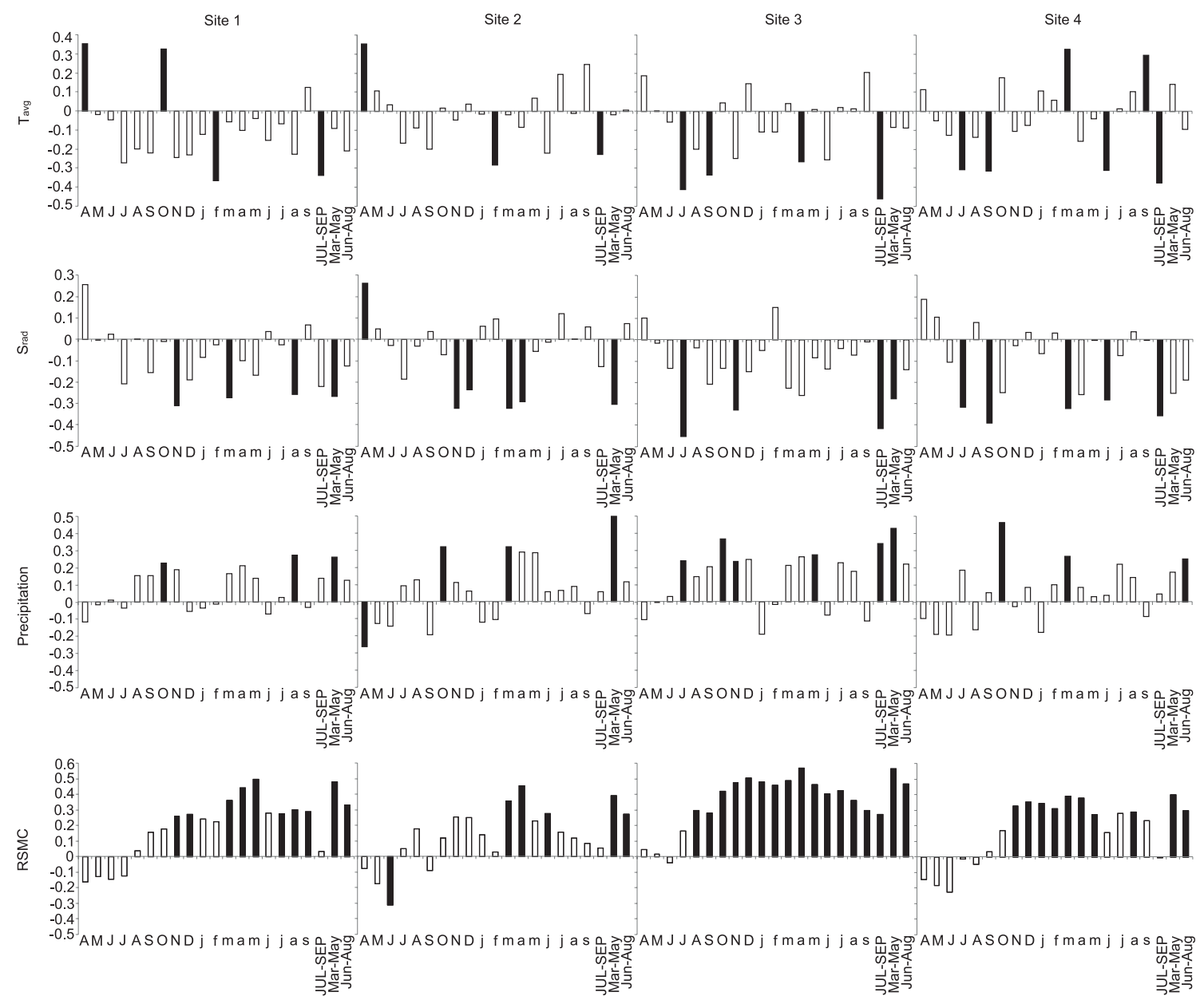

Fig. 4. Values of correlation coefficients of the site residual index tree-ring chronologies with Tavg = average monthly temperature, Precipitation $=$ monthly precipitation, $\mathrm{RSMC}=$ relative saturation of soil profile by soil water from top to $130 \mathrm{~cm}$ of depth and Srad = global radiation sums from previous April to September of the current year and the period July-September of the previous year (JUL-SEP) and the period March-May (Mar-May) and June-August (Jun-Aug) of the current year for 1961-2011. Values highlighted in black are statistically significant $(\alpha=0.05)$ 

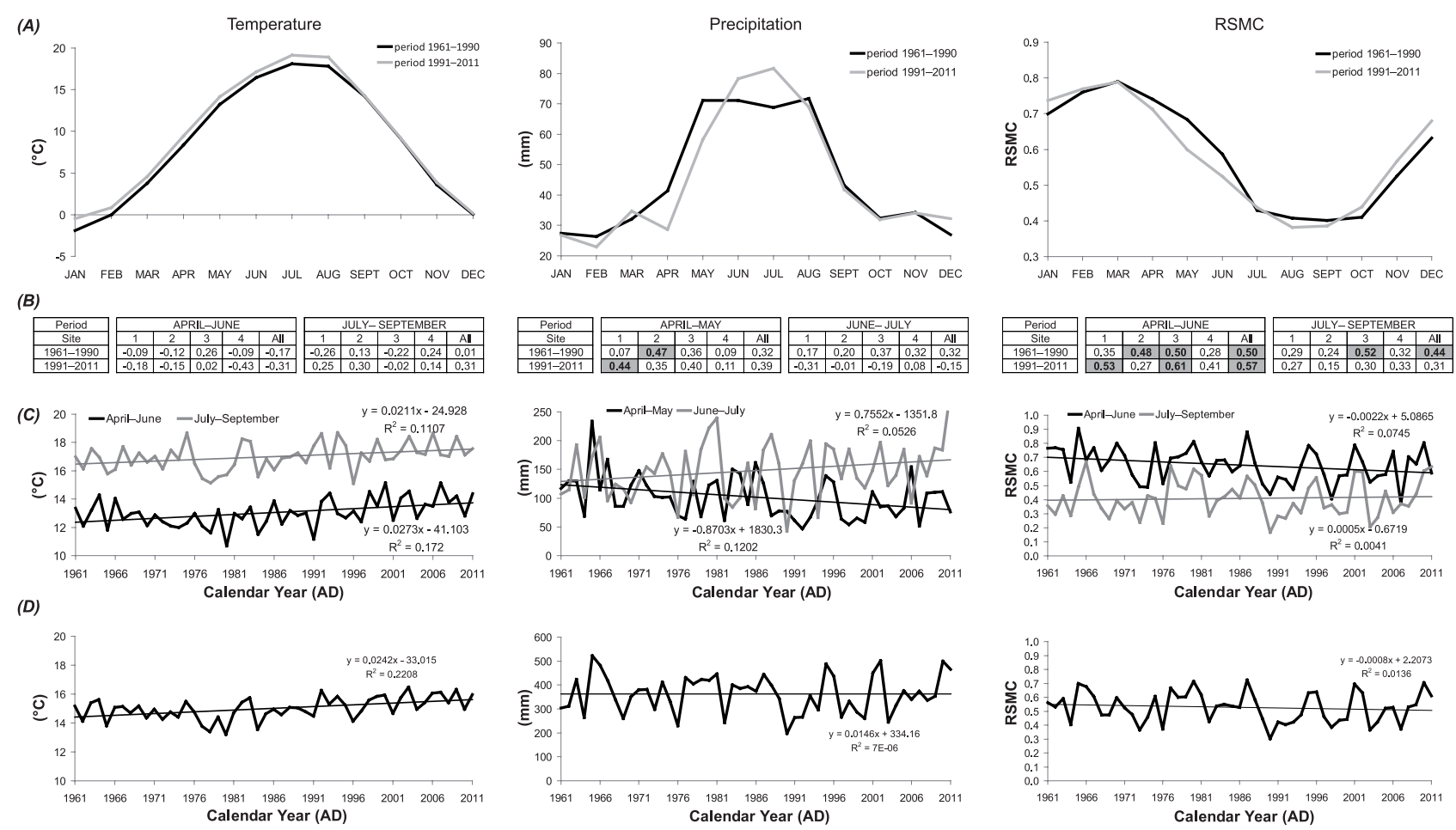

Fig. 5. (A) The progress of monthly temperature, precipitation and relative soil moisture content (RSMC in WMO (World Meteorological Organization) normal period 1961-1990 (black line) and 1991-2011 (grey line). (B) Mean temperatures, mean RSMC and sum precipitation for selected periods were correlated with the site chronologies. Statistically significant correlation coefficients are highlighted $(\alpha=0.05)$. (C) Temporal trends of the analysed climatic parameters for the selected periods. (D) Temporal trends of the analysed climatic parameters for the whole vegetation period

at some sites (summer - sites 3 and 4 , and autumn - sites 1, 2 and 3).

Distinct changes in trends of average monthly temperatures and precipitation in the period 1961-2011 have been revealed (Fig. 5). The average monthly temperatures increased in the first eight months of the year, with the most pronounced increase in January by $1.44{ }^{\circ} \mathrm{C}$. The spring (AprilJune) and the summer (July-September) trends are similar. The considerable reduction of spring precipitation (mainly April and May) is highly important for the growth of oaks. By contrast, a high rise of summer precipitation was observed especially in June and July. In consequence of the changed precipitation distribution, also the RSMC considerably decreased at the end of spring (May). The summer values of RSMC have no significant trend (Fig. 5). The changes in global radiation were negligible and they are not presented in Fig. 5.

The decline in spring precipitation leading to the reduction of RSMC resulted in a higher significance of the relationships between April-May precipitation (especially site 1) and April-June RSMC (all sites except 2) with the tree-ring width (Fig. 5). By contrast, the correlation coefficients of June-July precipitation changed from positive to negative and the correlation coefficients of July-September RSMC decreased.

\section{Discussion}

Some of the ascertained correlations between climatic parameters and tree-ring width are well known. The positive significant correlations between precipitation and tree-ring width or between RSMC and tree-ring width predominate (e.g. Mérian et al., 2011; Petráš \& Mecko, 2011; Michelot et al., 2012; Gillner et al., 2013; Sanders et al., 2014; Rybníček et al., 2015). A negative effect of summer temperatures on tree-ring width has been reported in other European areas, such as France (Michelot et al., 2012), Germany (Gillner et al., 2013), Slovakia (Petráš \& Mecko, 2011), and Austria, Hungary, Slovenia, Croatia and Serbia (Čufar et al., 2014). Petráš \& Mecko (2011) also determined a positive effect of precipitation at the end of the previous growing season on radial growth. The positive significant correlations with October precipitation were also found in many European studies (Friedrichs et al., 2009; Mérian \& Lebourgeois, 2011; Petráš \& Mecko, 2011; Michelot et al., 2012; Gillner et al., 2013). Oaks can profit from higher temperatures and sufficient precipitation in the previous October. The photosynthetic activity ending in the October and the character of weather determine speed of leaf colour changes and the term of leaf fall. Barbaroux and Bréda (2002) showed for sessile oak in France that October is very important 
for the translocation of sugar and starch to the main stem, i.e. for the final carbohydrate reserve in stem wood. The higher temperature and sufficient precipitation enable later leaf fall and higher final non-structural carbohydrate concentration. The significance of water available for oaks from the soil in autumn of the previous year has been confirmed by the positive significant correlations between RSMC and tree-ring width for October, November, and December (Fig. 4). Significant negative correlations with radiation sums in November and December (Fig. 4) show that earlywood formation can be affected by soil moisture loss caused by higher evaporation on bright days without snow cover after the leaves fall (Vanassche, 2011). The bigger global radiation sums lead to smaller water supply in spring.

The correlation between tree-ring width index and RSMC or radiation sum probably demonstrates the positive influence of a sufficient water supply for the optimal development of foliage at the beginning of the growing season (Lebourgeois et al., 2003).

There were other significant relations between RSMC and tree-ring width at the following time periods; it was the case of the dry site 3 for all months until autumn, in the case of the other sites for some of the months. As regards precipitation, significance has been mainly observed for the precipitation sums in spring (March-May) at all sites, except site 4 . Probable reasons for the higher values of correlation coefficients of RSMC when compared to precipitation are the higher evaporation in higher temperatures and a high variability of rainfall intensity. The same monthly precipitation sum may be caused by numerous light and moderate rains or only several heavy rains. The surface runoff in both situations will differ as different amounts of water will be supplied to the soil profile.

Growth response of site 1 with Quercus robur is similar to site 2 with Quercus petraea; both of these sites have more similar correlations than site 2 compared to site 3 with $Q$. polycarpa, Q. dalechampii, and site 4 with Q. petraea (Fig. 4). According to some of the published studies, Quercus robur had a greater response to climate, especially to precipitation, than Q. petraea (e.g. Friedrichs et al., 2009); other studies claim the opposite, that $Q$. petraea is the more sensitive species (e.g. Popa et al., 2013; Sanders et al., 2014). This discrepancy additionally leads us to the understanding that the differences between sites are more important than the difference between oak species. From the perspective of site differences, mainly the considerably stronger growth response to RSMC at site 3 , i.e. the site with dry shallow soil on a steep south-eastern slope, is notable. The majority of trees at this site have small tree-ring width variability (Tab. 2 ) and the tree-ring width is significantly affected by RSMC in all months starting from previous August to September of the current year (Fig. 4). The explanation by site characteristics is also applicable to the significant positive correlation between temperature and tree-ring width at site 4 in March (Fig. 4). The site has a north exposition, it is a valley bottom where cool water flows and it is a location prone to temperature inversion. The March temperatures can thus be limiting for the beginning of ring formation.

In spite of the above listed differences of response to climatic parameters, the TRW chronologies of the individual sites manifest high values of statistical indicators ( $t$-tests and Gleichläufigkeit). Most of the pointer years found in TRW chronologies also coincide at the different sites (Fig. 3). The results show that the similarity of the chronologies at the regional level is mainly dependent on the oak species and site conditions, and less on the distance of the stands. Lower correlations were found for nearby sites 3 and 4 (distance app. $2 \mathrm{~km}$ ) than for more distant sites 2 and 4 (app. $10 \mathrm{~km}$ ). This relationship can be caused either by the same oak species at the sites (both $Q$. petraea) and a different species at site $3(Q$. polycarpa and $Q$. dalechampii), or by the more extreme conditions at site 3 . Site 3 differs by a stronger dependence of radial growth on soil moisture when compared with the other sites. The species difference has likely also caused the lowest resemblance in the TRW chronology of site 1 ( $Q$. robur) with the other TRW chronologies; its distance is approximately the same as in the case of sites 2 and 3 or 4 . Despite all these differences, the achieved values of statistical indicators are very high (Fig. 3) and totally applicable for the purposes of dendrochronological dating and creation of TRW chronologies.

The observed climate trends, i.e., the precipitation decrease in the first half and the increase in the second half of the growing season (Fig. 5), were reported from other parts of the Czech Republic in the last twenty years (Možný et al., 2009, 2012; Bauer et al., 2010; Trnka et al., 2014). As a consequence of the decreased April and May monthly precipitation sums, the significance of spring rainfalls and spring RSMC increased after 1990 (except site 2). Our results show that the observed changes in the climate seriously affect the climate response of tree rings. The longterm trends in the frequency of drought-conducive circulation patterns have contributed to a change in the duration and intensity of drought episodes, especially during the early growing season (Trnka et al., 2009a) and at drier sites. This is very important for the radial growth of Quercus spp. as well as for the net primary production of Central European forests as a whole. As a number of studies predicted, increased drying during the growing seasons all over Central Europe (e.g. Seneviratne et al., 2006; Olesen et al., 2012; Trnka et al., 2013) might lead to an increased frequency of years during which the growth will be 
negatively affected. In fact, tree mortality and forest decline due to severe drought events have been observed in forest populations in Southern Europe (e.g. Affolter et al., 2010) but also in Belgium (Kint et al., 2012), Switzerland (Rigling et al., 2013) and the pre-Alps in France (e.g. Charru et al., 2010). This, together with other abiotic and biotic risks reported by IPCC: Climate Change 2014. Intergovernmental Panel on Climate Change; [cited 2014 Jan 18]. Available from: http://ipcc-wg2.gov/AR5/press-events/ press-kit, is likely to constitute a major challenge for forestry in Europe.

The high resemblance of the stands analysed supports the present day practice i.e. that millenia-long oak chronologies (e.g. Tegel et al., 2010; Büntgen et al., 2011; Koláŕ et al., 2012a) can contain any species from the group of 'white oaks'. This approach is partly forced by the fact that the wood of these species is hardly distinguishable at the macroscopic level and distinction is also difficult at the microscopic level. Differentiation of Quercus robur and Quercus petraea has also been dealt with by e.g. Feuillat et al. (1997) or Hroš \& Vavrčík (2014), but without a clear conclusion. The methodolgy of Feuillat et al. (1997) was applied to research into subfossil oak trunks in Tovačov (Koláŕ et al., 2012b), but the method success rate is around $78 \%$ (Feuillat et al., 1997). The method is also highly time consuming and difficult to use for e.g. archaeological wood as its condition often prevents this method application. Oak TRW chronologies are often used for the reconstruction of past climatic conditions (e.g. Büntgen et al., 2010; Tegel et al., 2010; Wilson et al., 2012). There is the question whether the species variability can reduce the climatic signal contained within tree rings. The results achieved indicate that the same species growing at different sites responds differently than two different species growing at similar sites. In addition, TRW chronologies manifest the same growth trends throughout the species and sites.

\section{Conclusions}

1. At the level of tree-ring width, no significant differences have been found between the particular species and particular sites; by contrast, the particular TRW chronologies manifested a high resemblance.

2. The amount of water available in the soil (RSMC) is the main climate affected limiting factor of radial growth in the conditions of Český kras. The same situation can be expected in other locations of Central Europe. With respect to the ongoing and expected changes in rainfall distribution, the RSMC is clearly a more suitable parameter to evaluate tree growth response to drought than precipitation sums.

3. The growth response of the particular oak species to climatic factors (correlations) at the same or close locations differed negligibly; in other words, differences caused by oak species cannot be clearly identified. On the other hand, the effect of the site has proved to be essential. Mainly in the case of moisture extreme sites (fast runoff, low groundwater levels, low soil water holding capacity), we can expect that radial growth will be more responsive to the climate drivers during extreme years.

4. After 1990 the distribution of rainfalls has changed within the growing season at the expense of spring (April, May) rainfalls.

5. The significance of RSMC spring values for oak growth has increased and the significance of summer values for oaks has decreased as a result. If this trend continues, we can expect the reduction of radial growth.

\section{Acknowledgments}

The paper was prepared within the European Social Fund, the state budget of the Czech Republic - "Project Indicators of Tree Vitality" (reg. no. CZ.1.07/2.3.00/20.0265); the Czech Republic Grant Agency through the grant numbered 13-04291S; with funding from Ministry of Education, Youth and Sports of CR within the National Sustainability Program I (NPU I), grant number LO1415 and of the KONTAKT project LD13030 and the "Frameworks and possibilities of forest adaptation measures and strategies connected with Climate change" (no. EHPCZ02-OV-1-019-2014) and project IGA 28/2014.

\section{References}

Affolter P, Büntgen U, Esper J, Rigling A, Weber P, Luterbacher J \& Frank D (2010) Inner Alpine conifer response to 20th century drought swings. European Journal of Forest Research 129: 289-298.

Allen RG, Pereira LS, Raes D \& Smith M (1998) Crop evapotranspiration. Guidelines for computing crop water requirements. FAO Irrigation and drainage paper 56. Food and Agriculture Organization of the United Nations, Rome 300: D05109.

Allen CD, Macalady AK, Chenchouni H, Bachelet D, McDowell N, Vennetier M, Kitzberger T, Rigling A, Breshears DD, Hogg EH, Gonzalez P, Fensham R, Zhang Z, Castro J, Demidova N, Lim J-H, Allard G, Running SW, Semerci A \& Cobb N (2010) A global overview of drought and heat-induced tree mortality reveals emerging climate change 
risks for forests. Forest Ecology and Management 259: 660-684.

Baillie MGL \& Pilcher JR (1973) A simple crossdating program for tree-ring research. Tree-Ring Bulletin 33: 7-14.

Barbaroux C \& Bréda N (2002) Contrasting distribution and seasonal dynamics of carbohydrate reserves in stem wood of adult ring-porous sessile oak and diffuse-porous beech trees. Tree Physiology 22: 1201-1210.

Bauer Z, Trnka M, Bauerová J, Možný M, Štěpánek P, Bartošová L \& Žalud Z (2010) Changing climate and the phenological response of great tit and collared flycatcher populations in floodplain forest ecosystems in Central Europe. International Journal of Biometeorology 54: 99-111.

Biondi F \& Waikul K (2004) DendroClim2002: $\mathrm{AC}++$ program for statistical calibration of climate signals in tree ring chronologies. Computers and Geosciences 30: 303-311.

Bošela $M$, Sedmák R, Marušák R, Sedmáková $D$, Petráš R \& Barna M (2014) Evaluating similarity of radial increments around tree stem circumference of European beech and Norway spruce from Central Europe. Geochronometria 41: 136-146.

Brázdil R, Trnka M, Dobrovolný P, Chromá K, Hlavinka P \& Žalud Z (2009) Variability of droughts in the Czech Republic, 1881-2006. Theoretical and Applied Climatology 97: 297-315.

Büntgen U, Trouet V, Frank D, Leuschner HH, Friedrichs D, Luterbacher J \& Esper J (2010) Treering indicators of German summer drought over the last millennium. Quaternary Science Reviews 29: 1005-1016.

Büntgen U, Tegel W, Nicolussi K, McCormick M, Frank D, Trouet V, Kaplan JO, Herzig F, Heussner K-U, Wanner H, Luterbacher J \& Esper J (2011) 2500 years of European climate variability and human susceptibility. Science 331: 578-582.

Cedro A (2007) Tree-ring chronologies of downy oak (Quercus pubescens), pedunculate oak (Q. robur) and sessile oak (Q. petraea) in the Bielinek Nature Reserve: Comparison of the climatic determinants of tree-ring width. Geochronometria 26: 39-45.

Charru M, Seynave I, Morneau F \& Bontemps J-D (2010) Recent changes in forest productivity: an analysis of national forest inventory data for common beech (Fagus sylvatica L.) in north-eastern France. Forest Ecology and Management 260: 864-874.

Čufar K, Grabner M, Morgos A, Martinez del Castillo E, Merela M \& De Luis M (2014) Common climatic signals affecting oak tree-ring growth in SE Central Europe. Trees 28: 1267-1277.

Dostál J (1989) Nová květena ČSSR. Academia, Praha.
Eckstein D \& Bauch J (1969) Beitrag zur rationalisierung eines dendrochronologischen verfahrens und zur analyse seiner aussagesicherheit. Forstwissenschaftliches Centralblatt 88: 230-250.

Feuillat F, Dupouey JL, Sciama D \& Keller R (1997) A new attempt at discrimination between Quercus petraea and Quercus robur based on wood anatomy. Canadian Journal of Forest Research 27: 343-351.

Friedrichs D, Büntgen U, Esper J, Frank D, Neuwirth B \& Löffler J (2009) Complex climate controls on 20th century oak growth in Central-West Germany. Tree Physiology 29: 39-51.

Fritts HC, Mosimann JE \& Bottorff CP (1969) A revised computer program for standardizing treering series. Tree-Ring Bulletin 29: 15-20.

Fritts HC (1976) Tree rings and climate. Academic Press, London, New York, San Francisco.

Fritts HC \& Swetnam TW (1989) Dendroecology: A tool for evaluating variations in past and present forest environments. Advances in Ecological Research 19: 111-188.

Gillner S, Vogt J \& Roloff A (2013) Climatic response and impacts of drought on oaks at urban and forest sites. Urban Forestry and Urban Greening 12: 597-605.

Gričar J (2010) Xylem and phloem formation in sessile oak from Slovenia in 2007. Wood Research 55: 15-22.

Grissino-Mayer HD, Holmes R \& Fritts HC (1992) International tree-ring data bank program library. Version 1.1. Laboratory of Tree-Ring Research, University of Arizona, Tucson.

Hlavinka P, Trnka M, Balek J, Semerádová D, Hayesc M, Mark Svobodac M, Eitzingerd J, Možnýe M, Fischera M, Huntc E \& Žaluda Z (2011) Development and evaluation of the SoilClim model for water balance and soil climate estimates. Agricultural Water Management 98: 1249-1261.

Hlavinka P, Trnka M, Semerádová D, Dubrovský M, Žalud Z \& Možný M (2009) Effect of drought on yield variability of key crops in Czech Republic. Agricultural and Forest Meteorology 149: 431442.

Holmes RL, Adams RK \& Fritts HC (1986) Tree-ring chronologies of western North America: California, eastern Oregon and northern Great Basin with procedures used in the chronology development work including users manuals for computer programs COFECHA and ARSTAN. Chronology Series VI. Laboratory of Tree - Ring Research, University of Arizona, Tuscon.

Hollstein E (1980) Mitteleuropäische eichenchronologie. Trierer dendrochronologische forschungen zur archäologie und kunstgeschichte. Trierer Grabungen und Forschungen. Mainz am Rhein.

Horáček P, Šlezingerová J \& Gandelová L (2003) Analysis of cambial activity and formation of wood in 
Quercus robur L. under conditions of a floodplain forest. Journal of Forest Science 49: 412-418.

Hroš M \& Vavrčík H (2014) Comparison of earlywood vessel variables in the wood of Quercus robur L. and Quercus petraea (Mattuschka) Liebl. growing at the same site. Dendrochronologia 32: 284-289.

Jovanovič B (2000) Dendrologija. Belgrade University, Belgrade.

Kint V, Aertsen W, Campioli M, Vansteenkiste D, Delcloo A \& Muys B (2012) Radial growth change of temperate tree species in response to altered regional climate and air quality in the period 1901-2008. Climatic Change 115: 343-363.

Koblížek J (1990) Quercus L.: Květena ČR 2 (ed. by S Hejný \& B Slavík) Academia, Praha, pp. 21-35.

Koláŕ T, Kyncl T \& Rybníček M (2012a) Oak chronology development in the Czech Republic and its teleconnection on a European scale. Dendrochronologia 30: 243-248.

Kolář T, Gryc V, Rybníček M \& Vavrčík H (2012b) Anatomical Analysis and Species Identification of Subfossil Oak Wood. Wood Research 57: 251264.

Kolář T, Rybníček M \& Tegel W (2013) Dendrochronological evidence of cockchafer (Melolontha sp.) outbreaks in subfossil tree-trunks from Tovačov (CZ Moravia). Dendrochronologia 31: 29-33.

Lebourgeois F, Cousseau G \& Ducos Y (2003) Étude d'une chênaie sessiliflore exceptionnelle: la futaie des Clos (Sarthe). Revue forestière française 55: 333-346.

Magic D (2006) Quercus L.: Flóra Slovenska V/3 (ed. by $\mathrm{K}$ Goliášová $\mathrm{K} \& \mathrm{~N}$ Michálková) Veda, Bratislava.

Matyas V (1971) Short taxonomic review of the oaks of Hungary. Erdészeti Kutatàsok Budapest 67: $55-68$.

Mérian P, Bontemps JD, Bergès L \& Lebourgeois $\mathrm{F}$ (2011) Spatial variation and temporal instability in climate-growth relationships of sessile oak (Quercus petraea [Matt.] Liebl.) under temperate conditions. Plant Ecology 212: 1855-1871.

Mérian P \& Lebourgeois F (2011) Size-mediated climate-growth relationships in temperate forests: A multi-species analysis. Forest Ecology and Management 261: 1382-1391.

Michelot A, Breda N, Damesin C \& Dufrene E (2012) Differing growth responses to climatic variations and soil water deficits of Fagus sylvatica, Quercus petraea and Pinus sylvestris in a temperate forest. Forest Ecology and Management 265: 161-171.

Možný M, Tolasz R, Nekovář J, Sparks T, Trnka M \& Žalud Z (2009) The impact of climate change on the yield and quality of Saaz hops in the Czech Republic. Agricultural and Forest Meteorology 149: 913-919.
Možný M, Brázdil R, Dobrovolný P \& Trnka M (2012) Cereal harvest dates in Czech Republic between 1501 and 2008 as proxy for March-June temperature reconstruction. Climatic Change 110: 801821.

Olesen JE, Børgesen CD, Elsgaard L, Palosuo T, Rötter RP, Skjelvåg $\mathrm{AO}$, Peltonen-Sainio $\mathrm{P}$, Börjesson T, Trnka M, Ewert F, Siebert S, Brisson N, Eitzinger J, van Asselt ED, Oberforster M \& van der Fels-Klerx HJ (2012) Changes in time of sowing, flowering and maturity of cereals in Europe under climate change. Food Additive and Contaminants 29: 1527-1542.

Parry ML (2000) Assessment of potential effects and adaptation for climate change in Europe: The Europe ACACIA Project. Jackson Environment Institute, University of East Anglia, Norwich, United Kingdom.

Petráš R \& Mecko J (2011) Effect of climatic factors on the dynamics of radial increments of Norway spruce, European beech and sessile oak. Journal of Forest Science 57: 293-302.

Popa I, Leca S, Crăciunescu A, Sidor C \& Badea O (2013) Dendroclimatic response variability of Quercus species in the Romanian intensive forest monitoring network. Notulae Botanicae Horti Agrobotanici Cluj-Napoca 41: 326-332.

Požgaj J \& Horváthová J (1986) Variabilita a ekológia druhov rodu Quercus L. na Slovensku. Veda, Bratislava.

Rigling A, Bigler C, Eilmann B, Feldmeyer-Christe E, Gimmi U, Ginzler C, Graf U, Mayer P, Vacchiano G, Weber P, Wohlgemuth T, Zweifel R \& Dobbertin M (2013) Driving factors of a vegetation shift from Scots pine to pubescent oak in dry Alpine forests. Global Change Biology 19: 229-240.

Rozas V (2005) Dendrochronology of pedunculate oak (Quercus robur L.) in an old-growth pollarded woodland in northern Spain: tree-ring growth responses to climate. Annals of Forest Science 62: 209-218.

Rybníček M, Čermák P, Žid T \& Koláŕ T (2010a) Radial growth and health condition of Norway spruce (Picea abies (L.) Karst.) stands in relation to climate (Silesian Beskids, Czech Republic). Geochronometria 36: 9-16.

Rybníček M, Koňas P \& Kolár T (2010b) The benefits of tree-ring curves detrending for dating archaeological wood. Geochronometria 35: 85-90.

Rybníček M, Čermák P, Hadaš P, Kolář T \& Žid T (2012a) Dendrochronological analysis and habitual stress diagnostic assessment of Norway spruce (Picea abies) stands in the Drahany highlands. Wood Research 57: 189-206.

Rybníček M, Čermák P, Žid T \& Kolář T (2012b) Growth responses of Picea abies to climate in the 
central part of the Českomoravská Upland (Czech Republic). Dendrobiology 68: 21-30.

Rybníček M, Čermák P, Žid T, Kolář T, Trnka T \& Büntgen U (2015) Exploring growth variability and crown vitality of sessile oak (Quercus petraea) in the Czech Republic. Geochronometria 42: 1727.

Sanders TGM, Pitman R \& Broadmeadow MSJ (2014) Species-specific climate response of oaks (Quercus spp.) under identical environmental conditions. iForest 7: 61-69.

Seneviratne SI, Luthi D, Litschi M \& Schar C (2006) Land-atmosphere coupling and climate change in Europe. Nature 443: 205-209.

Šíma P (2007) Květena východní části Českého krasu. Bohemia centralis 28: 117-202.

Šmelko Š \& Wolf J (1977) Štatistické metódy v lesníctve. Príroda, Bratislava.

Štěpánek P (2007) ProClimDB - software for processing climatological datasets. CHMI, regional office Brno. Available from: http://www.climahom.eu/ProcData.html

Tegel W, Vanmoerkerke J \& Büntgen U (2010) Updating historical tree-ring records for climate reconstruction. Quaternary Science Reviews 29: 1957-1959.

Thomas FM, Blank R \& Hartmann G (2002) Abiotic and biotic factors and their interactions as causes of oak decline in Central Europe. Forest Pathology 32: 277-307.

Tolasz R (2007) Atlas podnebí Česka. Český hydrometeorologický ústav, Univerzita Palackého v Olomouci, Olomouc, Praha.

Trnka M, Kyselý J, Možný M \& Dubrovský M (2009a) Changes in Central-European soil-moisture availability and circulation patterns in 1881-2005. International Journal of Climatology 29: 655-672.

Trnka M, Dubrovský M, Svoboda M, Semerádová D, Hayes M, Žalud Z \& Wilhite D (2009b) Developing Regional Drought Climatology for the Czech Republic. International Journal of Climatology 29: 863-883.

Trnka M, Olesen JE, Kersebaum KC, Skjelvag AO, Eitzinger J, Seguin B, Peltonen-Sainio P, Rötter R, Iglesias A, Orlandini S, Dubrovsky M, Hlavinka P, Balek J, Eckersten H, Cloppet E, Calanca P, Gobin A, Vucetic V, Nejedlik P, Kumar S, Lalic B, Mestre A, Rossi F, Kozyra J, Alexandrov V, Semeradova
D \& Zalud Z (2011) Agroclimatic conditions in Europe under climate change. Global Change Biology 17: 2298-2318.

Trnka M, Brázdil R, Olesen JE, Eitzinger J, Zahradníček P, Kocmánková E, Dobrovolný P, Štěpánek P, Možný M, Bartošová L, Hlavinka P, Semerádová D, Valášek H, Havlíček M, Horáková V, Fischer M \& Žalud Z (2012) Could the changes in regional crop yields be a pointer of climatic change? Agricultural and Forest Meterology 166: 62-71.

Trnka M, Kersebaum KC, Eitzinger J, Hayes M, Hlavinka P, Svoboda M, Dubrovský M, Semerádová D, Wardlow B, Pokorný E, Možný M, Wilhite D \& Žalud Z (2013) Consequences of climate change for the soil climate in Central Europe and the central plains of the United States. Climatic Change 120: 405-418.

Trnka M, Brázdil R, Možný M, Štěpánek P, Dobrovolný $\mathrm{P}$, Zahradníček $\mathrm{P}$, Balek J, Semerádová $\mathrm{D}$, Dubrovský M, Hlavinka P, Eitzinger J, Wardlow B, Svoboda M, Hayes M, Žalud Z (2015) Soil moisture trends in the Czech Republic between 1961 and 2012. International Journal of Climatology 35: 3733-3747.

Vanassche J (2011) Sap flow dynamics in sessile oak during drought stress events in the Czech Republique: 1976-1977 and 2007-2008 [dissertation]. Universiteit Gent, Gent.

Viewegh J, Kusbach A \& Mikeska M (2003) Czech forest ecosystem classification. Journal of Forest Science 49: 85-93.

Ważny T, Lorentzen B, Köse N, Akkemik Ü, Boltryk Y, Güner T, Kyncl J, Kyncl T, Nechita C, Sagaydak $S$ \& Vasileva JK (2014) Bridging the gaps in treering records: creating a high-resolution dendrochronological network for southeastern Europe. Radiocarbon 56: 39-50.

Wigley TML, Briffa KR \& Jones PD (1984) On the average value of correlated time series, with applications in dendroclimatology and hydrometeorology. Journal of Climate and Applied Meteorology 23: 201-213.

Wilson R, Miles D, Loader NJ, Melvin T, Cunningham L, Cooper R \& Briffa K (2012) A millennial long March-July precipitation reconstruction for southern-central England. Climate Dynamics 40: 997-1017. 